\title{
NOTES ON THE STATUS OF MAMMALIAN FAUNA OF THE LAWACHARA NATIONAL PARK, BANGLADESH
}

\author{
Md. Abdul Aziz \\ Department of Zoology \\ Jahangirnagar University, Savar, Dhaka 1342, Bangladesh \\ E-mail: maaziz@gmail.com
}

\begin{abstract}
This paper presents a checklist of mammalian species of the Lawachara National Park, Bangladesh with notes on their status and conservation threats. A total of 39 species belonging to seven orders and 21 families were recorded. Of these, Carnivora (38\%), Rodentia (24\%), Primates (15\%), Chiroptera (13\%) and Artiodactyla (5\%) were major. Thirty six per cent of the recorded mammals were common followed by uncommon (26\%), rare (23\%) and very common (15\%). Nationally, $51 \%$ of the recorded species face different categories of threats followed by not threatened (28\%) and data deficient $(21 \%)$. In terms of global status, $23 \%$ of the species are threatened and $73 \%$ species are under lower risk category. Primates, herbivores and carnivores face severe threats primarily stemming from habitat loss and fragmentation, wildlife poaching and human disturbance. Arresting illegal tree felling and over-exploitation of forest resources, restoration of degraded habitats and regulative tourism activities should urgently be addressed for long-term conservation of mammalian species in the park.
\end{abstract}

Key words: Bangladesh, mammals, Lawachara National Park, status, threats.

\section{INTRODUCTION}

Bangladesh is blessed with 121 species of mammals (IUCN 2000, Khan 2008). The presence of such a large number of species in a small densely populated country (160 millions human in $147570 \mathrm{~km}^{2}$ ) has been possible due to its geographic location in between Indo-Himalayas and Indo-China sub-regions. However, existing mammalian population indicates a clearly deteriorating trend during the past several decades (Siddiqui and Faizuddin 1981, Islam et al. 2006). This decline of mammalian population is being further accelerated by diverse and pervasive anthropogenic threats throughout their ranges. To date, $8 \%$ of the mammalian species have undergone to extinction from Bangladesh and $36 \%$ have been categorized as threatened (IUCN 2000). In addition, $44 \%$ of the mammalian species have been put under data deficient category, meaning that we have no information of their status and distribution in the country (IUCN 2000). But species occurrence and their status have always been proven worth to integrate into management and conservation activities. Despite having large number of studies over the last three decades in the Lawachara National Park (LNP) and adjoining areas (Feeroz 1999, Islam et al. 2006, 2008, Aziz 2007, Aziz and Feeroz 2007, Aziz et al. 2008), no consolidated checklist of mammals have come to light. Previously, all these studies were primarily 
focused on ecology, status and distribution, food and feeding behaviour of primates including some other aspects. As a result, there is an incomplete understanding of what mammalian species occur in the park, a deficiency in knowing how to manage those species for long-term conservation. To supplement this gap, current studies attempted to provide a preliminary checklist of the mammalian species with notes on threats they face and suggesting recommendations to ameliorate those threats.

\section{STUDY AREA}

The Lawachara National Park, a part of the West Bhanugach Forest Reserve, is located approximately $160 \mathrm{~km}$ north east of Dhaka and 60 $\mathrm{km}$ south of the city of Sylhet in the civil administrative units of Kamalgonj Police Station and Maulvi Bazar District of Sylhet Forest Division (Fig. 1). The park is situated within $24^{\circ} 030^{\prime}-24^{\circ} 032^{\prime} \mathrm{N}$ and $91^{\circ} 037^{\prime}-91^{\circ} 039^{\prime} \mathrm{E}$ coordinates under the bio-ecological zone of $9 \mathrm{~b}$ Sylhet Hills (Nishat et al. 2002). The current notified area of the park covers 1250 ha and additional 281 ha of West Bhanugach Reserved Forest have been proposed for including along with the existing areas (FSP, 2000). The forest of the park is of semi-evergreen type which originally supported an indigenous vegetation cover of mixed tropical evergreen trees. Previously, almost all of the original forest cover has been removed or substantially altered and thus turned into a secondary forest type. The old plantations date back to around 1920's and gradually have developed a multistoried forest strata including undergrowth, creepers and naturally occurring tree species. Over the years, the oldest vegetation area have taken the structure of natural forests. In terms of human use, five other separated area of natural forests ( 130 ha) have been under betel leaf cultivation by the inside ethnic communities. More than hundred species of plants have so far been identified from the park forests (Leech and Ali 1997). Overall tree density was recorded as 528.5/ha. The canopy height varies from 10 to 30 $\mathrm{m}$ (Islam et al. 2006). Average maximum temperature $\left(33.6^{\circ} \mathrm{C}\right)$ was recorded in March and average minimum temperature of $10^{\circ} \mathrm{C}$ in January. The highest rainfall $(456 \mathrm{~mm})$ was recorded in June during the study period (Aziz 2007).

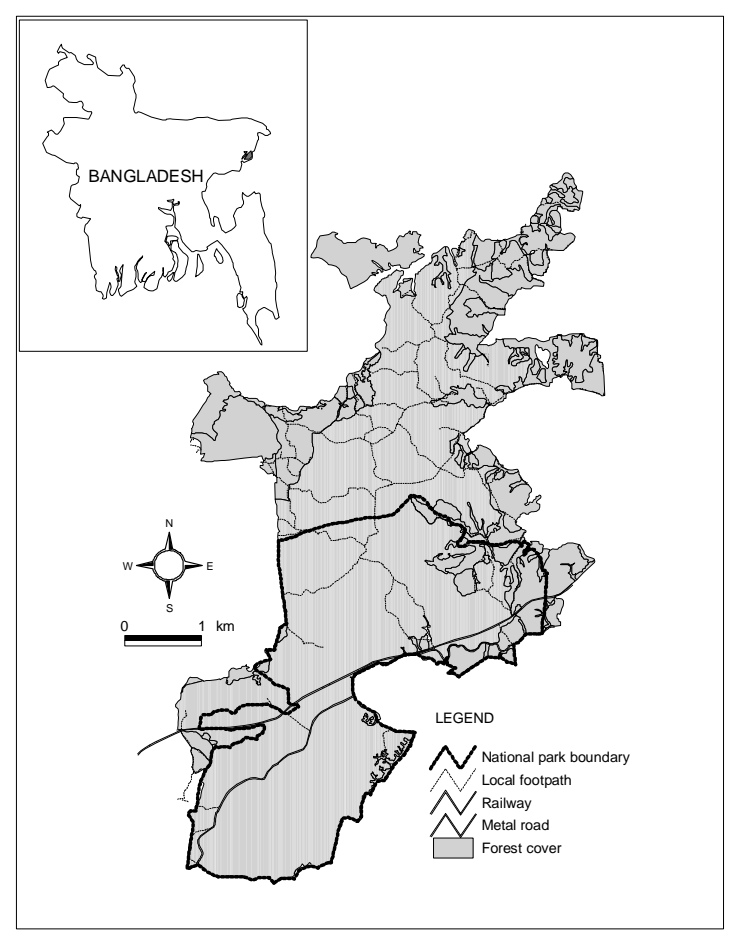

Fig. 1. Lawachara National Park, Bangladesh.

\section{MATERIALS AND METHODS}

This study was carried out between 2005 and 2007 to determine the presence of mammalian species in the LNP by using different standard approaches. The necessity of various methods arises due to diversity of mammalian species that occurred in the park. The following different methods were employed during this study.

Transect survey: The transect survey was conducted using existing forest paths, visitor trails or streams crossing different habitat types of the park following Islam et al. (2006) and Aziz (2007). Author with team members and local assistants walked slowly from dawn to dusk following transects. Local assistant of the Lawachara punji 
located inside the LNP, helped finding out potential habitats of cryptic mammals that increased the likelihood of spotting as much mammalian species as possible. During traversing through transects, a $10 \mathrm{~min}$ pause was made to listen calling of mammals or to scan surrounding canopy for determining presence of mammals. This transect walking was repeated covering all existing paths, visitor trails, streams crisscrossed the park to ensure exhaustive count. Digital DSC-H50 Sony Cybershot camera was also used for taking photographs for detail identification. Visual observations were aided with binoculars $(12 \times 50)$ whenever necessary.

Sign survey: The presence of mammalian species was ascertained by the presence of different signs left by animals. For this survey, presence of quills, scats, tracks, trails, hair/fur, feeding signs, etc. were recorded and analyzed by using standard protocols. Different habitat types, water holes, streams, resting and feeding areas were emphasized for sign survey.

Capture survey: Mist nests were deployed for capturing bats in different habitat types, homesteads of two communities located inside the park, and park staff houses. The nests were deployed from $16.30 \mathrm{~h}$ to $20.30 \mathrm{~h}$ for a total of 9 trap nights in 6 locations. Bats captured were immediately released from the net after taking morphometric measurements following Bates and Harrison (1987) and unidentified individuals were preserved with $70 \%$ alcohol for skull analysis. For capturing rats and mice, five rat traps were posted with baits within the houses of the forest staff and also on the trees in the forests. Captured animals were measured and identified with help of the Book of Indian Animals (Prater 1980).

Photo card interview: Photo card interview has been a useful method to determine the species presence or absence for wildlife species (Aziz et al. 2008). In this study, randomly selected respondents of different stakeholders such as forest resource user groups, forest patrolling groups, members of co-management council and comanagement committee, eco-guides were interviewed with pictorial guides and photographs of likely species of mammals. Forest user groups (fuel wood collectors, daily workers involved with forest management, beneficiaries of social forestry practices, nursery owners) were selected randomly from Lawachara and Magurchara Punji located inside the park, Tipra Para located southwest, Garo Basti located northwest, and Kalapur village located northwest of the national park. In addition, few key informants were interviewed to substantiate information provided by respondents. For identification of the mammalian species, colourful photographs were developed in addition to the Book of Indian Animals (Prater 1980, Aziz et al. 2008).

Status assessment: Current status of the mammalian species was assessed by combined metric of visual sightings during transect walking, frequency of respondent sightings and signs of occurrence. Assessment rating was determined as very common (>75\% sightings), common (50-74\% sightings), uncommon (25-49\% sightings) and rare ( $<24 \%$ sightings). National and global status of the recorded species has been analysed by using status assessment carried out by the IUCN (2000) and IUCN (2006) respectively.

\section{RESULTS}

A total of 39 mammalian species under seven orders and 21 families were recorded during this study (Table 1). The highest number of species was recorded from the order Carnivora (38\%) while lowest from Insecta (3\%) and Lagomorpha (3\%). Of the 21 families, Muridae (24\%), Viverridae (24\%), Felidae (19\%), Pteropidae (14\%), Scuirridae (14\%) and Herpestidae (14\%) were major. Under the Carnivora, a total of 14 species belonging to six families were known with 
highest number from the Viverridae (36\%) followed by Felidae (29\%) and Herpestidae (21\%). The Viverrids were mostly rare and uncommon. Among felids, the Prionailurus viverrinus was fairly common while the remaining two were rare and uncommon. The Herpestes auropunctatus and H. edwardsi under Herpestidae were fairly common while H. urva was rare. The Ursus thibetanus has nearly disappeared, however, few fecal signs and respondent opinions were noted. Respondents also have sighted the Martes flavigula in the park which can be the first record for Bangladesh. Among rodents, five species of rats and mice, three species of squirrels and one species of porcupine were recorded. Of the squirrels, both Callosciurus pygerythrus and Dremomys lokriah were fairly common while remaining Petaurista magnificus was extremely rare. The Vandeleuria oleracea was uncommon and noticed at several occasions on the trees just before and after sun set while remaining species were caught from the houses of BFD staff and Khasia communities. The Hystrix indica was recorded by presence of their quills and feeding signs in the agricultural farms located next to the park boundary. Of the primates, the Macaca leonina, Macaca mulatta and Trachypithecus pileatus were commonly observed while the Trachypithecus phayrei and Nycticebus bengalensis were uncommon and rare respectively. Five species of chiropterans were recorded with a good population of all four species except the Indian Flying Fox which was found coming in the park to forage just before dusk. Among artiodactyls, the Sus scrofa was found with a good population but Muntiacus muntjak has become extremely rare.

Table 1. Checklist of mammalian fauna (Class: Mammalia) of the Lawachara National Park of Bangladesh with notes on their status

\begin{tabular}{|c|c|c|c|c|c|c|c|}
\hline \multirow[t]{2}{*}{ SN } & \multirow[t]{2}{*}{ Family } & \multirow[t]{2}{*}{ Scientific Name } & \multirow[t]{2}{*}{ English Name } & \multirow[t]{2}{*}{ Local Name } & \multicolumn{3}{|c|}{ Status $^{1}$} \\
\hline & & & & & $\begin{array}{l}\text { This } \\
\text { study }\end{array}$ & $\begin{array}{l}\text { IUCNB } \\
2000\end{array}$ & $\begin{array}{l}\text { IUCN } \\
2006 \\
\end{array}$ \\
\hline \multicolumn{8}{|c|}{ ORDER: INSECTIVORA } \\
\hline 1. & Soricidae & Suncus murinus & House Shrew & Chika/Chucho & $\mathrm{C}, \mathrm{D}$ & NO & $\mathrm{LC}$ \\
\hline \multicolumn{8}{|c|}{ ORDER: CHIROPTERA } \\
\hline 2. & Pteropidae & Cynopterus sphinx & $\begin{array}{l}\text { Short-nosed Fruit } \\
\text { Bat }\end{array}$ & $\begin{array}{l}\text { Bocha Kola } \\
\text { Badur }\end{array}$ & $\mathrm{V}, \mathrm{C}$ & DD & $\mathrm{LC}$ \\
\hline 3. & Pteropidae & Pteropus giganteus & Indian Flying Fox & Badur & $\mathrm{V}, \mathrm{D}$ & NO & $\mathrm{LC}$ \\
\hline 4. & Pteropidae & $\begin{array}{l}\text { Rousettus } \\
\text { leschenaulti }\end{array}$ & Fulvus Fruit Bat & Kola Badur & $\mathrm{C}, \mathrm{C}$ & DD & $\mathrm{LC}$ \\
\hline 5. & Megadermatidae & Megaderma lyra & $\begin{array}{l}\text { Greater False } \\
\text { Vampire }\end{array}$ & Daini Badur & $\mathrm{V}, \mathrm{C}$ & NO & $\mathrm{LC}$ \\
\hline 6. & Vespertilionidae & $\begin{array}{l}\text { Pipistrellus } \\
\text { coromandra }\end{array}$ & India Pipistrelle & Chamchika & $\mathrm{C}, \mathrm{C}$ & NO & $\mathrm{LC}$ \\
\hline \multicolumn{8}{|c|}{ ORDER: PRIMATES } \\
\hline 7. & Loridae & $\begin{array}{l}\text { Nycticebus } \\
\text { bengalensis }\end{array}$ & $\begin{array}{l}\text { Bengal Slow } \\
\text { Loris }\end{array}$ & Lojjawati Banor & $\mathrm{R}, \mathrm{P}$ & $\mathrm{CR}$ & VU \\
\hline 8. & Cercopithecidae & Macaca mulatta & Rhesus macaque & Banor & $\mathrm{V}, \mathrm{D}$ & VU & $\mathrm{LC}$ \\
\hline 9. & Cercopithecidae & Macaca leonina & $\begin{array}{l}\text { Pig-tailed } \\
\text { Macaque }\end{array}$ & Ultoleji Banor & C, D & $\mathrm{CR}$ & VU \\
\hline 10. & Colobidae & $\begin{array}{l}\text { Trachypithecus } \\
\text { phayrei }\end{array}$ & $\begin{array}{l}\text { Phayre's Leaf } \\
\text { Monkey }\end{array}$ & $\begin{array}{l}\text { Chosmapora } \\
\text { Hanuman }\end{array}$ & $\mathrm{U}, \mathrm{D}$ & $\mathrm{CR}$ & EN \\
\hline 11. & Colobidae & $\begin{array}{l}\text { Trachypithecus } \\
\text { pileatus }\end{array}$ & Capped Langur & $\begin{array}{l}\text { Mukhpora } \\
\text { Hanuman }\end{array}$ & C, D & EN & VU \\
\hline 12. & Hylobatidae & Hoolock hoolock & $\begin{array}{l}\text { Western Hoolock } \\
\text { Gibbon }\end{array}$ & Ulluk & $\mathrm{V}, \mathrm{D}$ & $\mathrm{CR}$ & VU \\
\hline
\end{tabular}


ORDER: CARNIVORA

\begin{tabular}{|c|c|c|c|c|c|c|c|}
\hline 13. & Canidae & Canis aureus & $\begin{array}{l}\text { Asiatic Golden } \\
\text { Jackal }\end{array}$ & Pati Shial & $\mathrm{C}, \mathrm{D}$ & VU & $\mathrm{LC}$ \\
\hline 14. & Felidae & Felis chaus & Jungle Cat & Ban Biral & $\mathrm{U}, \mathrm{P}$ & EN & $\mathrm{LC}$ \\
\hline 15. & Felidae & $\begin{array}{l}\text { Prionailurus } \\
\text { bengalensis }\end{array}$ & Leopard Cat & Chita Biral & $\mathrm{U}, \mathrm{P}$ & DD & $\mathrm{LC}$ \\
\hline 16. & Felidae & $\begin{array}{l}\text { Prionailurus } \\
\text { viverrinus }\end{array}$ & Fishing Cat & Mecho Biral & $\mathrm{C}, \mathrm{P}$ & EN & EN \\
\hline 17. & Felidae & Neofelis nebulosa & Clouded Leopard & Gecho Bagh & $\mathrm{R}, \mathrm{P}$ & $\mathrm{CR}$ & $\mathrm{VU}$ \\
\hline 18. & Herpestidae & $\begin{array}{l}\text { Herpestes } \\
\text { auropunctatus }\end{array}$ & $\begin{array}{l}\text { Small Indian } \\
\text { Mongoose }\end{array}$ & Benji & $\mathrm{C}, \mathrm{D}$ & NO & $\mathrm{LC}$ \\
\hline 19. & Herpestidae & Herpestes edwardsi & $\begin{array}{l}\text { Common } \\
\text { Mongoose }\end{array}$ & Bara Benji & C, D & VU & $\mathrm{LC}$ \\
\hline 20. & Herpestidae & Herpestes urva & $\begin{array}{l}\text { Crab-eating } \\
\text { Mongoose }\end{array}$ & Kakrabhuk Benji & $\mathrm{R}, \mathrm{D}$ & EN & $\mathrm{LC}$ \\
\hline 21. & Ursidae & Ursus thibetanus & $\begin{array}{l}\text { Asiatic Black } \\
\text { Bear }\end{array}$ & Kalo Bhalluk & $\mathrm{R}, \mathrm{P}$ & EN & VU \\
\hline 22. & Viverridae & Arctictis binturong & Binturong & Gecho Bhalluk & $\mathrm{R}, \mathrm{P}$ & $\mathrm{CR}$ & VU \\
\hline 23. & Viverridae & Paguma larvata & $\begin{array}{l}\text { Masked Palm } \\
\text { Civet }\end{array}$ & Ghanda Gokul & $\mathrm{R}, \mathrm{D}$ & EN & $\mathrm{LC}$ \\
\hline 24. & Viverridae & $\begin{array}{l}\text { Paradoxurus } \\
\text { hermaphroditus }\end{array}$ & $\begin{array}{l}\text { Common Palm } \\
\text { Civet }\end{array}$ & Ghanda Gokul & $\mathrm{R}, \mathrm{D}$ & VU & $\mathrm{LC}$ \\
\hline 25. & Veverridae & Viverra zibetha & $\begin{array}{l}\text { Large Indian } \\
\text { Civet }\end{array}$ & Bagdash & $\mathrm{U}, \mathrm{P}$ & EN & NT \\
\hline 26. & Veverridae & Viverricula indica & $\begin{array}{l}\text { Small Indian } \\
\text { Civet }\end{array}$ & Khatash & $\mathrm{U}, \mathrm{P}$ & VU & $\mathrm{LC}$ \\
\hline 27. & Mustelidae & Martes flavigula & $\begin{array}{l}\text { Yellow-throated } \\
\text { Marten }\end{array}$ & -- & $\mathrm{P}$ & -- & $\mathrm{LC}$ \\
\hline \multicolumn{8}{|c|}{ ORDER: ARTIODACTYLA } \\
\hline 28. & Suidae & Sus scrofa & Wild Boar & Shuar & $\mathrm{V}, \mathrm{D}$ & NO & $\mathrm{LC}$ \\
\hline \multicolumn{8}{|c|}{ ORDER: RODENTIA } \\
\hline 30. & Sciuridae & $\begin{array}{l}\text { Callosciurus } \\
\text { pygerythrus }\end{array}$ & Irrawardy Squirrel & $\begin{array}{l}\text { Badami } \\
\text { Kathbirali }\end{array}$ & $\mathrm{V}, \mathrm{D}$ & NO & $\mathrm{LC}$ \\
\hline 31. & Sciuridae & Dremomys lokriah & $\begin{array}{l}\text { Orange-bellied } \\
\text { Himalayan } \\
\text { Squirrel }\end{array}$ & Kalo Kathbirali & $\mathrm{V}, \mathrm{D}$ & DD & $\mathrm{LC}$ \\
\hline 32. & Sciuridae & $\begin{array}{l}\text { Petaurista } \\
\text { magnificus }\end{array}$ & $\begin{array}{l}\text { Hodgon's Giant } \\
\text { Flying Squirrel }\end{array}$ & Uranta Kathbirali & $\mathrm{R}, \mathrm{P}$ & $\mathrm{DD}$ & NT \\
\hline 33. & Muridae & Mus musculus & House Mouse & Nengti Indur & C, D & NO & LC \\
\hline 34. & Muridae & Rattus rattus & $\begin{array}{l}\text { Common House } \\
\text { Rat }\end{array}$ & Indur & C, D & NO & $\mathrm{LC}$ \\
\hline 35. & Muridae & $\begin{array}{l}\text { Vandeleuria } \\
\text { oleracea }\end{array}$ & $\begin{array}{l}\text { Asiatic Long- } \\
\text { tailed Climbing } \\
\text { Mouse }\end{array}$ & Gecho Idur & $\mathrm{U}, \mathrm{D}$ & DD & $\mathrm{LC}$ \\
\hline 36. & Muridae & $\begin{array}{l}\text { Bandicota } \\
\text { bengalensis }\end{array}$ & $\begin{array}{l}\text { Lesser Bandicoot } \\
\text { Rat }\end{array}$ & Indur & U, D & $\mathrm{NO}$ & LC \\
\hline 37. & Muridae & Bandicota indica & $\begin{array}{l}\text { Greater Bandicoot } \\
\text { Rat }\end{array}$ & Baro Indur & $\mathrm{U}, \mathrm{D}$ & NO & $\mathrm{LC}$ \\
\hline 38. & Hystricidae & Hystrix indica & $\begin{array}{l}\text { Indian Crested } \\
\text { Porcupine }\end{array}$ & Shojaru & $\mathrm{C}, \mathrm{S}$ & EN & $\mathrm{LC}$ \\
\hline \multicolumn{8}{|c|}{ ORDER: LAGOMORPHA } \\
\hline 39. & Leporiade & Lepus nigricollis & $\begin{array}{l}\text { Rufous-tailed } \\
\text { Hare }\end{array}$ & Khargosh & $\mathrm{U}, \mathrm{P}$ & EN & $\mathrm{LC}$ \\
\hline
\end{tabular}

${ }^{1}$ Status Code: V-Very Common, C-Common, U-Uncommon, R-Rare; DD-Data Deficient, NO/NT-Not Threatened, LC-Least Concern, VU-Vulnerable, EN-Endangered, CR-Critically Endangered; D-Direct sighting, C-Capture, PPeople sighting, S-Sign occurrence 
In terms of status assessed of the recorded mammalian species, $36 \%$ species were common followed by uncommon (26\%), rare $(23 \%)$ and very common (15\%). According to IUCN (2000), $51 \%$ of the recorded species face different categories of threats followed by not threatened (28\%) and data deficient (21\%). Of the threatened species, $15 \%$ species were critically endangered, $23 \%$ endangered and $13 \%$ vulnerable. In terms of global status assessed by IUCN (2006), 23\% of the known species are threatened comprising of endangered (5\%) and vulnerable (18\%) categories. Furthermore, $73 \%$ species are under lower risk category comprising of least concerned $(72 \%)$ and not threatened (5\%) (Fig. 2).

Threats to mammals and their habitats are diverse and pervasive in the LNP. Unlimited demands for forest resources of the surrounding human population are tremendous and posing serious threats to mammals and their habitats. Habitat degradation and fragmentation, wildlife poaching and disturbance were the major threats identified during this study. There are strong evidences that illegal timber extraction has been commonplace in the LNP. Field observations suggest that some organised groups consisting of poor local people backing and persuaded by local timber merchants and influential elite are involved with this illegal tree felling. Besides timber poaching, non-timber forest products (NTFPs) were being heavily exploited by large number of people regularly for household use or for selling in the local market. In addition, betel leaf cultivation practices by the Khasia tribes inside the LNP is another threat to wildlife and forest ecosystem which involve weeding of forest floor and lopping of lower branches of trees regularly.

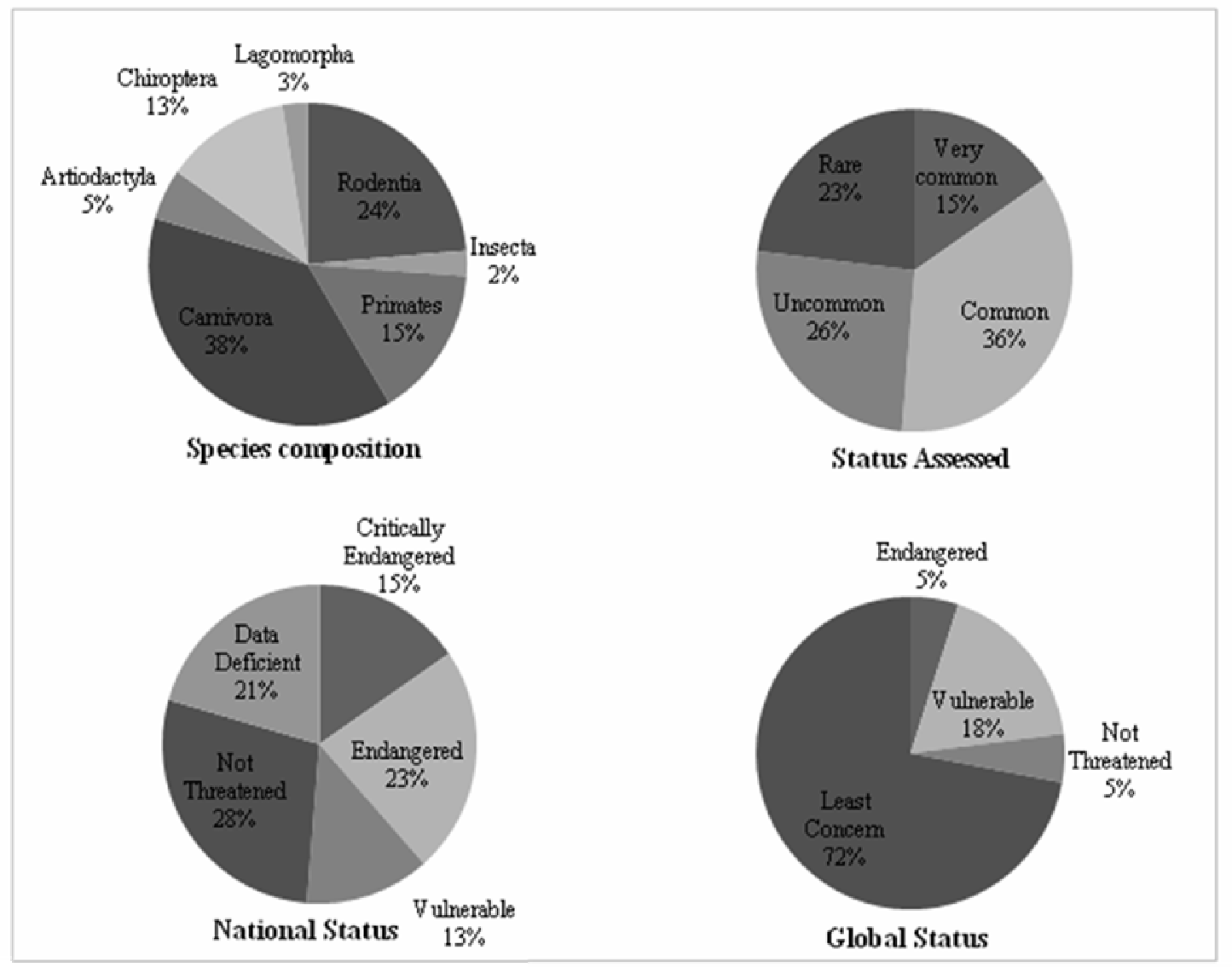

Fig. 2. Species composition and status of mammalian species in the LNP 
Large scale wildlife poaching or hunting was non-existent in the park. However, respondents opined that the Gallus gallus and Gracula religiosa, Muntiacus muntjak and sometimes even primates were targeted for hunting by local communities. Study also noted that wildlife fauna such as monkeys, birds and squirrels were occasionally trapped and sold to local agent of poachers.

Currently, tourism activities in the LNP have immensely increased after the promotion of tourism through co-management approach under Nishorgo Support Program by the BFD since 2004. However, no effective rules and regulations have yet been in place for managing tourists and visitors' activities friendly to forest and wildlife therein. As a result, chasing wildlife, playing high volume music, leaving non-degradable wastes and creating chaos have become common place in the park nowadays.

\section{DISCUSSION}

The checklist presented is the first of its kind covering almost all of the major mammalian groups. However, the list is not exhaustive but to be considered as the baseline to integrate for better management of the park as well as for the mammals. Previous studies reported occurrence of some mammals, namely, 6-8 species of mammals mentioned by several workers (Leech and Ali 1997), 6 species of non-human primates by Feeroz (1999). However, Khan (1982) reported on the sighting of the Panthera pardus but this study did not find any such information to support its presence in the park.

Most of the viverrids were rare and uncommon as noted in this study. One reason behind this rarity might be their cryptic and nocturnal habits and thus occasional encounter to the respondents interviewed. Earlier study reported that this national park has been the home for one of the largest population of the Hoolock hoolock comprising of 42 individuals in 11 social groups (Islam et al. 2006). The Macaca leonina, M. mulatta and Trachypithecus pileatus were commonly observed while the Trachypithecus phayrei and Nycticebus bengalensis were uncommon and rare respectively (Aziz 2007, Aziz and Feeroz 2009a). A good number of social groups of the former three primate species were recorded while few groups and individuals were noted for the later two. All species of bats except the Pteropus giganteus have been found to roost within the houses of BFD staff and Khasia communities from where they had been netted (Aziz 2009). However, extensive and long-term study on chiropterans can raise this number in future. The Callosciurus pygerythrus and Dremomys lokriah were frequently found throughout the park while the Petaurista magnificus occasionally noticed in the areas of traditional betel leaf cultivation (Aziz and Feeroz 2009b). The park also supports a good number of Sus scrofa which have been known to become menace to nearby agricultural farms in addition to the Hystrix indica (Aziz and Feeroz 2007). Another artiodactyl, the Muntiacus muntjak has nearly undergone to extinction locally due to illegal hunting and poaching (Aziz 2007).

Unlimited demands of the growing human population living in and around the park have left the mammalian species and their forest habitats in peril. Despite having several initiatives in place by the BFD to abate dependency on forest resources for the last few years, such efforts, however, practically demonstrated very little tangible outcomes in the field. Illegal tree felling has been widespread in the LNP which is thought even quite large. Available reports suggest that annual illegal logging in 2005-2006 averaged to 1188 trees in Lawachara National Park alone (Muzaffar et al. 2011). Although, these occurrences are primarily attributed to inadequate staff, logistics and 
equipment; however, greed and frail morale of the park officers and staff are also questionable in this regard (Feeroz and Islam 2000). These studies noted that the Tectona grandis, Artocarpus chaplasha and other large timber trees are being cut regularly. The Artocarpus chaplasha was regarded as one of the important fruit trees for primates, rodents and birds and removal of this tree is resulting in acute food scarcity in addition to canopy detachment and disruption. Betel leaf cultivation practices by the Khasia tribe have been thought to be affecting ecosystem integrity, particularly eroding soil and driving wildlife away from those areas. In addition, available reports suggest that people from 11 villages surrounding the park also collect substantial amount of NTFPs regularly (Feeroz and Islam 2000). Furthermore, the plantation practices carried out by the forest department have been thought to bring out adverse consequences to the forest ecosystem and integrity and thus the mammalian habitats.

The Muntiacus muntjak, Sus scrofa and Macaca mulatta usually become the prime targets for hunting and trapping in addition to Gallus gallus and Gracula religiosa. This study also found that some local people trapped wildlife species such as monkeys, birds and squirrels for selling to local agent of poachers; similar observations were also reported by CNRS (2000). Nevertheless, anecdotal reports and respondent's opinion suggest that some local people haunt for wildlife for a local zoo located at Sreemongal town which have also been proved by regular visits there.

Tourism activities are unmanaged and regulative mechanisms are non-existent in the LNP despite having eco-guides available for tourists for guided tourism. In addition, cattle grazing by the local and some inside people, fodder collection, hunting and other resource exploitation, gas exploration activities, etc. also noted as threats to wildlife and ecosystem integrity. Ahsan (2003) indentified the link of declining hoolock population with that of habitat destruction, tourism activities and gas exploration.

In conclusion, the checklist provided is not exhaustive and could be used as a baseline to contribute in future park management plan. Illegal poaching of trees are urgently required arresting forest/habitat loss and fragmentation to support long term conservation of mammals. In this connection, government's will, sufficient logistic and skilled, dedicated BFD staff, regulative and controlled tourism activities are strongly recommended.

\section{ACKNOWLEDGEMENTS}

Author is grateful to Jahangirnagar University authority for providing financial support for this study. Many individuals and research students of the Zoology Department of Jahangirnagar university accompanied author in the field and helped carry out netting and trapping. Thanks also go to anonymous reviewers for their comments that helped improve the manuscript.

\section{REFERENCES}

Ahsan, M.F. 2003. Distribution of Hoolock Gibbon (Bunopithecus hoolock hoolock) in India and Bangladesh. Zoos Print Journal 18:969-976.

Aziz, M.A. 2007. Utilization of Forest Flora by the Mammalian Fauna of the Lawachara National Park, Bangladesh (unpublished). M.Phil. Thesis, Department of Zoology, Jahangirnagar University, Savar, Dhaka, Bangladesh.

Aziz, M.A. 2009. Notes on Greater False Vampire bat from Lawachara National Park, Bangladesh. Small Mammal Mail 1:6-7.

Aziz, M.A. and M.M. Feeroz. 2007. Damage to agricultural crops by mammalian fauna at the fringes of Lawachara National Park, Bangladesh. Tiger Paper 34:29-32.

ECOPRINT VOL 18, 2011 
Aziz, M.A. and M.M. Feeroz. 2009a. Utilization of forest flora by Phayre's leaf monkey Trachypithecus phayrei (Primates: Cercopithecidae) in semi-evergreen forest of Bangladesh. Journal of Threatened Taxa 1:257-262.

Aziz, M.A. and M.M. Feeroz. 2009b. Utilization of forest flora by the Orange-bellied Himalayan Squirrel (Dremomys lokriah) in a semi-evergreen forest of Bangladesh. Bangladesh J. Life Sci. 21:39-45.

Aziz, M.A., M.M. Feeroz and S. Sultana. 2008. Perceptions on biodiversity issues among the local people living in and around the Lawachara National Park, Bangladesh. Bangladesh J. Life Sci. 20:15-22.

Bates, P.J.J. and D.L. Harrison. 1997. Bats of the Indian Subcontinent. Harrison Zoological Museum, Kent, England, xvi+ 258 pp.

CNRS. 2000. Lawasera, Tropical Forest of Bangladesh. Rapid Rural Appraisal (RRA) Findings. Center for Natural Resources Studies, Dhaka, Bangladesh.

Feeroz, M.M. 1999. The Ecology and Behaviour of Pig-tailed Macaque (Macaca nemestrina leonina) in Bangladesh (unpublished). Ph.D. Thesis. University of Cambridge, Cambridge.

Feeroz, M.M. and M.A. Islam. 2000. Primates of the West Bhanugach Forest Reserve: major threats and management plan. In: Bangladesh Environment 2000. (ed.) Ahmed, M.F., BAPA Bangladesh Poribesh Andolon, pp. 239-253.

FSP (Forestry Sector Project). 2000. First Five Year Management Plan for Lawachara National Park. Vol. 1: Management Plan. Forest Department, Ministry of Environment and Forests, Dhaka.

Islam, M.A., M.M. Feeroz, S.B. Muzaffar, M.K., S. Begum, K. Hasan, S. Mahmud, and S. Chakma. 2008. Population status and conservation of hoolock gibbons Hylobates hoolock Harlan 1834 in Bangladesh. J. Bombay Nat. Hist. Soc. 105:19-23.
Islam, M.A., M.M. Feeroz, S.B. Muzaffar, M.M. Kabir and S. Begum. 2006. Conservation of the Hoolock Gibbons (Hoolock hoolock) of Bangladesh: population estimates, habitat suitability and management options. Technical Report, U.S. Fish and Wildlife Service, 48 pp.

IUCN Bangladesh. 2000. Red Book of Threatened Mammals of Bangladesh. IUCN-The World Conservation Union. Bangladesh, 31 pp.

IUCN. 2006. 2006 IUCN Red List of Threatened Species. <www.redlist.org>.

Khan, M.A.R. 1982. On the distribution of the mammalian fauna of Bangladesh. In: Proceeding of the Second National Forestry Conference, Bangladesh, pp. 560-575.

Khan, M.M.H. 2008. Protected Areas of Bangladesh - A Guide to Wildlife. Nishorgo Support Program, Bangladesh Forest Department, 304 pp.

Leech, J. and S.S. Ali. 1997. Extended Natural Resources Survey: Part IV - Plant and Animals Species Lists. GoB/WB Forest Resources Management Project, Technical Assistance Component. Mandala Agricultural Development Corporation, Dhaka, Bangladesh.

Muzaffar, S.B., M.A. Islam, D.S. Kabir, M.H. Khan, F.U. Ahmed, G.W. Chowdhury, M.A. Aziz, S. Chakma, and I. Jahan. 2011. Endangered Forests of Bangladesh: why the process of implementation of the Convention on Biological Diversity is not working. Biodiversity and Conservation. doi:10.1007/ s10531-011-0048-6.

Nishat, A., S.M.I. Huq, S.P. Barua, A.H.M. Ali Reza, A.S.M. Khan (eds.). 2002. Bioecological Zones of Bangladesh, IUCNBangladesh, Dhaka, 141 pp.

Prater, S.H. 1980. The Book of Indian Animals. Bombay Natural History Society, Bombay, 324 pp.

Siddiqui, N.A. and M. Faizuddin. 1981. Distribution and population status of some mammals in Bangladesh. Bano Biggyan Patrika 10:1-6. 